\title{
THE HILL OF WILD PRIVETS: FLORA IN THE TRADITIONAL CULTURE OF SLAVS
}

Гора калинова. Бильни свет у традиционалној култури словена. Зборник радова. Уредила Зоја Карановиһ. Београд: Удруженье фолклориста Србије, Университетска библиотека "Светозар Марковиһ”; Vilnius: Lietuviu kalbos instituto / Belgrade: Serbian Folklore Association, Svetozar Marković University Library; Vilnius: Lietuvių kalbos institutas, 2019, $416 \mathrm{pp}$.

The publication entitled "The Hill of Wild Privets: Flora in the Traditional Culture of Slavs" is a thematic anthology of works edited by Zoja Karanović. This is the fifth consecutive book authored or co-authored by this writer, which deals with the world of flora in the culture of Serbs and Slavs. The book is published by the Serbian Folklore Association, the University Library in Belgrade, and the Lithuanian Language Institute in Vilnius. This publication features twenty essays and three addenda which deal with human perception of the world of flora in the traditions of the abovementioned peoples from different points of view.

The authors of the published writings are eminent researchers from seven countries - Serbia, Bulgaria, Belarus, Lithuania, Russia, the USA, and Ukraine. Inna Shved and Tatiana Volodina hail from Belarus, P. Petrov is from Bulgaria, 
S. Tempchinas comes from Lithuania, while M. Babalyk, A. Ippolitova, K. Sharafadina, and V. Domanskij are from Russia. Authors from Serbia include: A. Vukmanović, Z. Koranović, S. Miloradović, R. Radić, T. Rakić, S. Samardžija, M. Stefanović and G. Štasni, while Ukraine is represented by N. Aksenova, I. Stavickaya, T. Shevchuk and L. Burkovskaya. Sophie Hodorowicz Knab's contribution comes from the USA. The essays were written in Serbian, Russian, and English.

The authors of this anthology deal with various subjects regarding the relationship the traditional man has towards the world of flora and his interaction with the material and symbolic dimensions of that world. Although it is often difficult to draw a sharp distinction between them, it is at least possible, to a certain degree, to classify them according to the theme and research subject.

Several essays represented within the anthology include individual plants and their place in Slavic traditions. Amongst them is the study entitled “Сосна в традиционной картине мира Белорусов" (The pine in the traditional worldview of Belorusians) by I. Shved, which presents the pine tree along with its diverse symbolic meanings. It shows there are many folklore stereotypes connected to it, such as those regarding the pine's appearance, origin, localization, the understanding of the tree as a locus, object of action, etc. As with other trees, the features and characteristics of the pine (both real and attributed) motivate its semiotic status and influence the formation of the symbolic appearance in the traditional image of the world of Belarusians and other Slavs. In the essay "Рожа (rose, роза) в украинском обрядовом фольклоре" (Rose in the Ukrainian ritual folklore) by T. Shevchuk, the author examines the ethnocultural characteristics of this phytonym in ritualistic folklore - in incantations for stopping bleedings and healing erysipela (рожа), a skin disease, as well as in Christmas, spring, St. John's Day, and wedding songs. The author also shows that in Ukrainian culture certain features of the rose are connected with folkloric Christian images and the birth of the Virgin Mary from its flower. I. Stavitskaya, in the essay "Сон-трава в украинской этноботанике" (The dream-plant in Ukrainian ethnobotany) analyses this plant from the buttercup family, examining the motivational aspect of its name and function in traditional culture based on its appearance, since the buttercup's petals close up at night and the flower bows down, as if to sleep. This is connected with the legend that this plant is the first to bloom because she was expelled from her country by her stepmother. Whilst she is waiting 
for her friends, she bows: печально склоняет голову и дремлет, как сирота ('sadly bows her head and slumbers like an orphan'). A prophetic power is also attributed to this plant, and the author illustrates this with impressive examples from folklore.

The usage of plants and their functions in rituals is examined in the essay entitled "The forgotten plants and herbs in the marriage customs of Poland" by S. Hodorowicz Knab. The author demonstrates how the world of flora as a whole occupied an important role in Polish culture, especially in rituals of passage, and primarily at weddings, where plants which were believed to symbolize virginity and fidelity were used, as were those with supposed healing, magic and aphrodisiac properties. In different situations and stages of a wedding an important role was played, for instance, by rosemary, the snake plant, wild privet, common mullein, lavender, cornflower, lovage, myrtle, rue.

In the essay "Кроз зелену гору ружмарина: пролазак кроз биљну гору" (Through green rosemary: Passing through the herbal mountains), A. Vukmanović examines different plant attributions which appear within the locus of hills in Serbian lyrical folk songs, and notes their functionality in the process of shaping that space. The author shows that through phytonymic "mediators" in traditional culture it is possible to structure the world, since in the songs hills that are associated with flowers, shrubs, and climber plants are surmountable to the heroes of the songs that are passing through them, whereas the hills which feature trees in their names are impassable areas. Z. Karanović also deals with the ways in which the world of flora functions in folk poetry in her essay “Тамодољен у џардине ја посејах боб и диње” (Down there in garden, I sowed beans and melons), which focuses on the introductory verses of lyrical folk songs featuring different kinds of plants. In her study "Глогов колац и тиква без корена. Биљни свет у Вуковој збирци пословица" (A hawthorn stake and a rootless gourd: Herbal world in Vuk's collection of proverbs) the author S. Samardzija deals with the symbolism of plants in folklore, pointing out how proverbs through floral symbolism reflect various spheres of man's life in the past. In sayings, for example, associations with the undergrowth are activated when the expression is directed towards tasks such as growing and harvesting fruits, according to the space in which plants grow or are cultivated, or used for food and drink.

Another segment of folklore, child's play, is represented in the essay entitled “Вегетативный код в традиционных играх Украинцев” (Vegetative code in 
traditional games of Ukrainians) by N. Aksenova. The author draws attention to the presence of a plant code in various children's games that are connected with, for instance, flax, poppy, millet, horseradish, radish. According to the author, these games played an important role during the growing up period and in understanding the idea of plant growth and maturation.

In addition to studying the world of flora through folklore, the authors in this anthology also examined old manuscripts and textual records, beginning with texts from the Byzantine era setting out the medicinal properties of the rose. A study by Р. Радић entitled "Ружа као лек (из византијског медицинског трактата)" (Ружа као лек (from the Byzantine medical tract)) deals with the rose and shows that this plant has been used in medicine and cosmetics since ancient times. The work also lists a large number of recipes for medicines which contained as an ingredient the rose, its flowers, syrup, and oil that were made by special procedures. Some essays also detail interesting views on the negative meanings certain plants carry, such as hops and tobacco, which were looked at from the angle of Christian tradition and its values. One such essay was submitted by M. Stefanović, under the heading “Веровања о дувану и беседа Вићентија Ракића о штетности дувана" (Beliefs about tobacco and a lecture of Vicentij Rakich about the harm of tobacco), while another example is “Растения хмель и табак в поздних старообрядческих сочинениях" (The plants of hops and tobacco in the late writings of Old Believers) by M. Babalyk. These essays show that hops and tobacco were presented as works of the devil. The article entitled "Плакун в русских рукописных травниках XVII-начала XX в" (Purple loosestrife in Russian handwritten herbalists from the $17^{\text {th }}$ to the beginning of the $20^{\text {th }}$ century) by A. Ippolitova can also be added to this group of essays. It deals with the textological analysis of the purple loosestrife plant in manuscript collections. Here the author, by examining the available variants of this phytonym, demonstrates how the records are transformed not just in folklore traditions, but in manuscript tradition as well.

Three authors featured in this anthology examine the functions and meanings of the floral world in the Slavic tradition through analysing works of written literature. They isolate the botanical images in the works of famous authors and offer interpretations of them. The first essay, "Симболика биља у дубровачким цингарескама” (Symbolism of plants from Dubrovnik) by T. Rakić, examines the ways plants are named and their symbolic meanings in carnival songs from Dubrovnik. The author notes that the developed floral 
iconography in these forms reflects folk beliefs in the magical and healing abilities of plants. Two essays, "Стратегии использования этноботанических ресурсов в записках охотника И. С. Тургенева” (Strategies for the use of ethnobotanical resources in the notes of hunter I.S. Turgenev) by K. Sharafadin, and "Семантика дендронимов в лирике Сергея Есенина" (The semantics of dendronyms in the lyrics of Sergei Yesenin) by V. Domanski deal with the functions of phytonyms encountered in the works of these famous writers. A detailed overview is given of the ethnobotanical and folkloric elements which they mention, as are their expert interpretations, which enrich the previously mentioned works with new meanings.

An etymological analysis of naming is provided in the essay entitled “Лит. žiedas, лтш. zieds 'цветок', ^ прусск. seydis 'стена' и южнослав ^zidь 'стена': о флористических истоках балто-славянского строительного термина" (Lit. žiedas, Lat. zieds 'flower', Old-Prussian. seydis 'wall' and South Slavic *zidb 'the wall': About the floral origins of the Balto-Slavic construction terms) by $\mathrm{S}$. Temchin, in which the author investigates the Lithuanian word žiedas and the Latvian word zieds, meaning 'flower', that are etymologically identical to the South Slavic ${ }^{\star} z i d z$ ' wall', with which they coincide in form but not in meaning. The nature of these relations is examined in the article. An analysis on the lexicological level is presented in the essay by G. Styasin, entitled "Лексички спојеви с компонентом јабука" (Lexical compounds with apple component), in which the author explores the different types of lexical connections with the intention of determining the concepts that are realized within syntagms, collocations, and idioms on the basis of the semantic content of this lexeme. Linguistic units of this type were selected for analysis because the apple occupies an important place in Serbian culture and tradition, which is reflected both on the linguistic level and on the level of mental lexicon.

L. Burkovska's article "Роль растительньіх мотивов в символической и стилистической системе украинской иконописи XVI-XVII вв” (The role of the plant-based motifs in the symbolic and stylistic system of Ukrainian iconography of the $16^{\text {th }}$ and $17^{\text {th }}$ centuries) demonstrates that the world of flora is equally important in the visual arts, such as icon painting. They carried a message about the significance and meaning of Flora for man through vegetative symbols (branches, leaves, floral ornaments - grapes and vine, pomegranate, lotus, lily, acanthus, carnation, cornflower) which appear on examined icons in combination with geometric patterns, six-petal rosettes, etc. 
The emergence of ethnobotany as a scientific discipline and its development and scope, i.e. the potential for ethnopharmacology to develop out of ethnobotany with the help of new ideas and technology is discussed by T. Volodina in the essay "Из истории этноботаники в Беларуси" (From the history of ethnobotany in Belarus). Furthermore, it is not only important to speak and sing about plants, but also to care for them and, like all other living creatures, they reciprocate the love, as pointed out in the essay "People-Plants Entanglements in Bulgarian Home Gardens" by P. Petrov, who discusses various plants which are being grown in private gardens in Bulgaria. They are old species and are considered signs of cultural heritage and local identity, carrying emotional value for the families that grow and care for them over many years.

There are three supplements in the book. The first one, entitled "Грађа за српскии мено слов биља (издела Захарије Орфелина)" (Materials for Serbain names of plants by Zaharie Orfelin) by M. Stefanović, is a dictionary of phytonyms in which Orfelin gives a systematic list of plants in his work "Велики српски травник и Искусни подрумар (1783)" (Great Serbian herbal book (1783)). The introductory note to his work also mentions the sources, structure, and content of this work, which is the oldest list of phytonyms in Serbia. In the supplement “Ботаника из Вукових 'Српских народних пословица” (Botanics from Vuk's' Serbian folk proverbs), S. Samardžija gives a tabular view of plants which appear in proverbs by Vuk Karadžić - another valuable contribution to the existing material regarding floral codes in the traditional culture of Serbs. "Куће опустеле, кровове падли, а на понекоји још расте чуваркућа (биљке у пословицама из пиротскога говора)" (Houses relaxed, roofs fell, and household keepers still grow (plants in Pirot dialect)), the supplement by S. Miloradović, gives a selection of more than 150 proverbs from the collection of Dragoljub Zlatković, from the region of Pirot (1988), which is also a testament to the existence of that dialect.

Viewed as a whole, the essays and supplements in this anthology deal with ancient experiences, knowledge and beliefs concerning plants, which have been transmuted into magic, rituals, and words. In segments of this book the authors discuss the world of flora and the functions of plants in oral tradition, various manuscripts containing descriptions of traditional methods of healing by the use of plants, as well as old recipes. The presence of plants in artistic literature is also discussed. The anthology features a series of supplements which, regardless of the fact that their authors have differing interests and come from 
different professional fields - folklorists, linguists, historians, literary historians and theorists, art historians - they are all united by a common core, the world of flora, with its meanings and functions in the traditional culture of Slavs. I also note that all the works were written with adherence to the scientific approach to research and are methodologically uniform regardless of the wide thematic span.

This anthology is therefore, along with the previous four, a treasure trove of knowledge and a refuge from oblivion for this important segment of Slavic traditional culture which is disappearing, but also taking on different forms in which the ancient magic knowledge and medicinal values of plants are morphing into so-called alternative medicine and pharmacology.

Nina Aksić

Institute of Ethnography SASA nina.aksic@ei.sanu.ac.rs

Nina Aksić, PhD, Research Associate in the Institute of Ethnography, Serbian Academy of Sciences and Arts, Serbia. Her work is based on Serbian folk tradition in Serbia and abroad. Other interests are historical and current culturalsocial life of Novi Pazar and cultural policy of SFR Yugoslavia. 